\title{
Study on the Developing Enameloid of a Fish (Hoplognathus fasciatus) II Effect of Tetracycline Injection
}

\author{
by \\ Yoshihisa TODA, * Tatsuo HASEGAWA, ${ }^{*}$ Toshiyuki KODAMA, * \\ Sakae TSUCHIDA, ${ }^{*}$ Kunimitsu YAMAGUCHI* and \\ Toraju KANEKO**

\section{Introduction}

Since the report by GRøN and JOHANNESSEN[1] on the affinity between tetracycline and calcium, BEVELANDER et al.[2], NyLEN et al.[3] and ANTALOvSKA et al.[4] confirmed the fact that, when tetracycline was administered to rats, there appeared fluorescence in the hypocalcified region of their enamel. Further, STOREY[5] and JoHnson[6] learned a diffuse fluorescence could be produced in the developing enamel of rats by the administration of tetracycline. Similarly, Hammarstrom[7] reported that tetracycline was intimately related to the primary mineralization of rat enamel formation.

The authors have been interested in a historadiographic study of mineralization process of fish enameloid[8,9,10] and concerned themselves, in the present report, with the appearance of fluorescence both in enameloid and dentin of Hoplognathus fasciatus by the administration of tetracycline.

\section{Material and Method}

By way of a study material, use was made of 40 Hoplognathus fasciatus, 10-20cm in length, which were raised at Aquarium of Suisan Kyodo Jiishujo, Chiba Prefecture. Each of these fish was intraperitoneally injected with a $5 \%$ solution of tetracycline in the amount of $25 \mathrm{mg} / \mathrm{Kg}$. From the 2 nd day of the injection to 30 th day, the fish were successively sacrificed and their jaw-bones removed. Both the upper and lower jaws were fixed by means of a neutral formalin solution and then embedded in polyester resin. They were subsequently cut by a thin sectioning machine to the thickness of 40 to $50 \mu$ to prepare them as ground sections: a fluorescence and its behavior generated in the ground sections was observed by the use of a fluorescence microscope.

\section{Observations}

In the jaw-bone of Hoplognathus fasciatus, there are embedded the successional teeth extending for 15 to 18 generations, the successors being consecutively arranged

\footnotetext{
* 戸田善久, 長谷川辰雄, 児玉俊之, 土田栄, 山口国光, Dept. of Anatomy, Nihon Univ. School of Dentistry, Tokyo. (Director: Professor Sohiti Isokawa)

** 金子虎寿, Chiba Prefecture Suisan Kyodo Jiishujo.
} 
covering those in the initial development to the completely developed ones[8, 9]. It follows, therefore, that one can find out the successors in respective developmental stages by observing their arrangements.

Figs. 1 and 2 give one such arrangement fluorescence-microscopically revealed, where Fig. 1 indicates a successor in the deep region of the jaw while Fig. 2 indicates one in the superficial region.

In the former, 5 bony crypts are noted, 4 of which contain teeth. When the deepest bony crypt is examined by the light microscope, a tooth in the earliest developmental stage associated with the formation of enameloid is observed. However, as this young tooth has no fluorescence, all we can see is the bony crypt.

On the other hand, with the second deeper bony crypt a fluorescence is found all over enameloid but it tends to reduce itself toward the superficial tooth (Fig. 1). Here 4 teeth are found that are considered as having completed their development; a fluorescence of enameloid and dentin is hardly noted (Fig. 2).

Figs. 3 and 4 are enlargements of a tooth that developed at the same time as that of Fig. 1. In Fig. 3, the organic matrix of enameloid has completed its future outline but the formation of dentin inside the enameloid cap has not taken place yet. A fluorescence is seen scattered all over enameloid, being particularly predominant in that part of enameloid adjacent to the dentinoenameloid junction. The right-hand tooth in Fig. 4 just began the formation of dentin. Although the fluorescence is strong in enameloid adjacent to the dentinoenameloid junction as in Fig. 3, it is much faded in the outer surface of enameloid. As regards the left-side tooth in which the formation of dentin is completed, a fluorescence of enameloid is faded and even dentin adjacent to enameloid lost its fluorescence. Fig. 5 gives a tooth in which the formation of dentin is further advanced; here we note the formation of a tissue called outer dentin[12] or Kragen[13] by different investigators. A fluorescence of enameloid is faintly observable in that portion adjacent to dentin. On the other hand, a strong fluorescence is seen in the area where dentin is being formed and also a diffuse fluorescence is observable in outer dentin. These findings are similarly seen in Fig. 1.

Fig. 6 gives a tooth which has completed its development almost entirely. In enameloid and dentin, a fluorescence has nearly disappeared except for predentin, its trace being faintly observable in dentinal tubules. On the other hand, a weak fluorescence still remains all over dentin.

\section{Discussion}

When tetracycline was intraperitoneally injected into Hoplognathus fasciatus, a fluorescence was generated in the portion where mineralization took place. With Hoplognathus fasciatus, this fluorescence is first observed in enameloid which appears diffusely after the organic matrix completed its future outline. The behavior of a fluorescence is similarly attested to in the enamel of rats and guinea pigs $[5,6,14]$. What is considered as peculiar to a fluorescence in Hoplognathus fasciatus is that it is particularly predominant in enameloid adjacent to the dentinoenameloid junction and that this fluorescence persists relatively long even after the progress of enameloid maturation. 
TSUBOUCHI[8] and IsoKaWA et al.[9] historadiographically studied the mineralization pattern of enameloid in the same sample. When their findings are compared with ours, we find that the behavior of radiopaque images of the historadiographs is more or less in parallel with that of fluorescence. However, the generation of a fluorescence corresponding to X-ray opaque image on the outer surface of enameloid is obscure. The areas of X-ray absorption will give more pronounced images according as the maturation progresses, while a diffuse fluorescence will tend to disappear soon.

The above behavior of fluorescence in enameloid confirmed the conclusion of SUGA[15] that "enamel has a peculiar mineralization mechanism".

As previously reported by AtKinson and Harcourt[16], Bevelander et al.[2], SUGA[15 [ and OWEN[17], a fluorescence in dentin takes place in the area where dentin is being formed and a deposition of inorganic salts exists. That is to say, a strong fluorescence is observable in that portion of dentin adjacent to predentin and it will disappear when the formation of dentin is completed. The fluorescence remains in dentinal tubules and, as suggested by ATKINSON and HARCOURT[16], the fluorescence may have a relation to the mineralization of peritubular matrix. On the other hand, there is a report to the effect that the peritubular hypercalcified zone cannot be historadiographically discovered in tubular dentin of fish (IsoKawA et al.[18]).

The behavior of fluorescence seen in outer dentin is similar to that seen in enameloid and, according to SATOMURA[19] and IsokAWA et al. [20], histologic findings of outer dentin are closer to dentin than enameloid.

\section{Conclusion}

Forty Hoplognathus fasciatus were intraperitoneally injected with tetracycline and, after the elapse of 2 to 30 days, their jaw bones were removed and the fluorescence generated in them was observed. The salient conclusions are as follows.

1. A fluorescence is generated in enameloid after the future outlines are completed by organic matrix.

2. A fluorescence appearing in enameloid is seen diffusely but it is particularly predominant in the area adjacent to the dentinoenameloid junction.

The fluorescence gradually disappears in proportion to the maturation or mineralization of enameloid.

3. With dentin, a fluorescence appears strongly in the area where dentin is being formed. However, its persists much longer in dentinal tubules.

4. A fluorescence appearing in outer dentin is similar to that seen in enameloid in that it takes place diffusely. However, it disappears in proportion to the progress of mineralization.

\section{References}

[1] Grøn, P. and Johannessen, L. B.: Fluorescence of tetracycline antibiotics in dentin; Acta odont. Scand., 19, 79-85, (1961).

[2] Bevelander, G., Rolle, G. K· and Cohlan, S. Q.: The effect of the administration of tetracycline on the development of teeth; J. dent. Res., 40, 1020-1024, (1961).

[3] Nylen, M. U., Omnell, K.-Å. and Lofgren, C.-G.: Fine structure of tetracycline-induced hypoplastic and hypomineralized defects in rats incisor enamel; J. dent. Res., 43, 850, (1964), (abst.). 
[4] Antalovské, Z.: Lows of tetracycline antibiotic deposition in rat incisor; J. dent. Res., 45, 1430-1438, (1966).

[5] Storey, E.: Cited from [7].

[6] Johnson, N. W.: Cited from [7]-

[7] Hammarström, L.: Different localization of tetracycline and simultaneously injected radiocalcium in developing enamel; Calc. Tiss. Res., 1, 229-242, (1967).

[8] Tsubouchi, M.: Mineralization pattern of the enamel of the teeth in Hoplognathus fasciatus; Nihon Univ. dent. J., 43, 444-450, (1969), (in Japanese).

[9] Isokawa, S., Tsubouchi, M., Aoki, K., Imai, M., Kawai, A. and Tsuchida, S.: Studies on the developing enameloid of a fish (Hoplognathus fasciatus) I. Mineralization pattern of enameloid Matrix; J. Nihon Univ. Sch. Dent., 12, pp. 43-49 (1970).

[10] Katsumata, A.: Mineralization pattern of the enameloid of the teeth in some teleostal fishes; Nihon Univ. dent. J., (in press).

[11] Poole, D. F. G.: Phylogeny of tooth tissues; enameloid and enamel in recent vertebrates with a note on the history of cementum; (Miles, A. E. W.: Structural and chemical organization of teeth; 1, Academic Press, New York and London), pp. 111-149, (1967).

[12] IsoKAwA, S.: Morphological studies on the teeth of fishes; I. On the teeth of porgies; Japan. J. Ichthyol., 3, 68-78, (1954), (in Japanese).

[13] Schmidt, W. J. and KeIL, A.: Die gesunden und die erkrankten Zahngewebe des Menschen und der Wirbeltiere in Polarisationomikroskop; Carl Hanser, München, S. 167-182, (1958).

[14] Suga, S. and Maruyama, Y.: Microradiographical, ${ }^{45} \mathrm{Ca}$ autoradiographical and tetracycline labeling study on the mineralization of guinea pigs enamel; Odontology, 53, 154-162, (1965).

[15] Suga, S.: Hard tissues and tetracycline; Shigaku, 53, 137-143, (1965), (in Japanese).

[16] Atkinson, H. F. and Harcourt, J. K.: Tetracycline in human dentine; Nature, 195, 508509, (1962).

[17] OwEN, L. N.: Fluorescences of tetracyclines in bone tumours, normal bone and teeth; Nature, 190, 500-502, (1961).

[18] Isokawa, S., Van Huysen, G. and Kosakai, T.: Historadiography of tubular enamel and dentin of osseous piscine teeth; J. Nihon Univ. Sch. Dent., 6, 79-87, (1964).

[19] Satomura, I.: A study on outer dentin of some teleostal fish teeth; Nihon Univ. dent. J., 43, 437-443, (1969), (in Japanese).

[20] Isokawa, S., Satomura, I., Yamaguchi, K., Yoshie, T. and Morimoto, M.: Histradiographic observations on the outer dentin in certain osseous fishes; J. Nihon Univ. Sch. Dent., 1-5, 12, (1970). 